
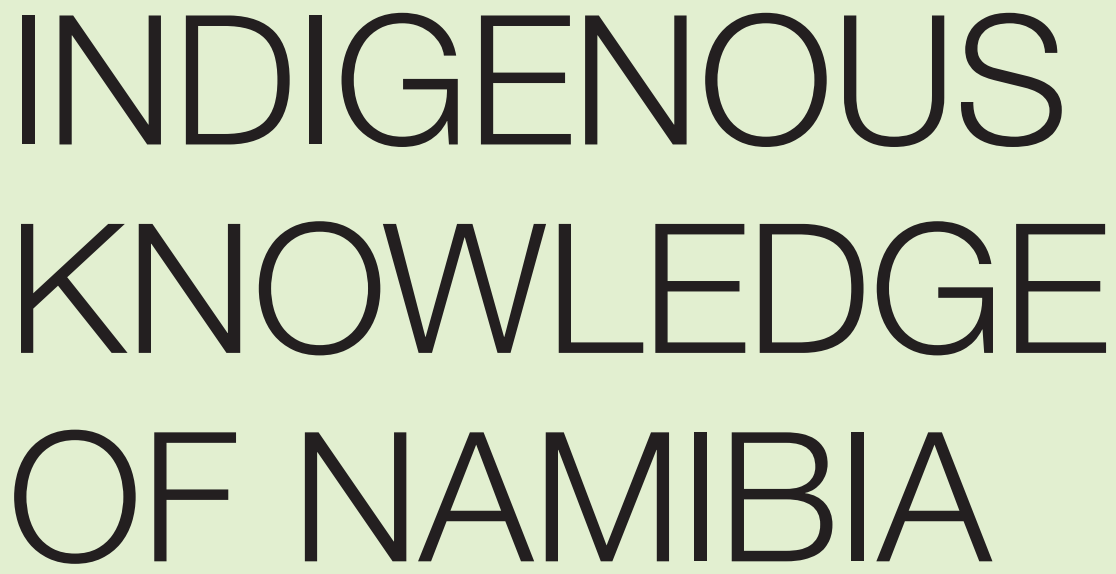
Indigenous knowledge is the dynamic information base of a society, facilitating communication and decision-making. It is the cornerstone of many modern-day innovations in science and technology. It is also a ready and valuable resource for sustainable and resilient livelihoods, and attracts increasing public interest due to its applications in bio-technology, health, bioprospecting, pharmaceuticals, agriculture, food preparation, mathematics and astronomy.

INDIGENOUS KNOWLEDGE OF NAMIBIA is a fascinating compendium aimed at a wide readership of academics and students, government officials, policy makers, and development partners. The 17 chapters examine the indigenous knowledge of medicinal plants for treating HIV/AIDS, malaria, cancer, and other microbial infections of humans and livestock; indigenous foods; coping and response strategies in dealing with human-wildlife conflicts, floods, gender, climate change and the management of natural resources. A new rationalisation of adolescent customary and initiation ceremonies is recommended in response to the HIV/AIDS pandemic; and a case study of the San people of Namibia speaks to the challenges of harmonising modern education with that of indigenous people.

The editors, Kazhila C. Chinsembu, Ahmad Cheikhyoussef, Davis Mumbengegwi, Martha Kandawa-Schulz, Choshi D. Kasanda and Lawrence Kazembe, are senior UNAM academics. Individual chapters are written by UNAM academics and post-graduate students from several disciplines in the natural and social sciences.

"Before I went to a formal school [i.e. Western education], I had the opportunity of playing cultural games like mulabalaba, kanamundame, kudoda and other cultural games with my contemporaries. These games opened my eyes that by the time I started school I could do basic counting. I could count my father's cattle because of the knowledge I obtained from the cultural games." (A teacher from Zambezi Region).

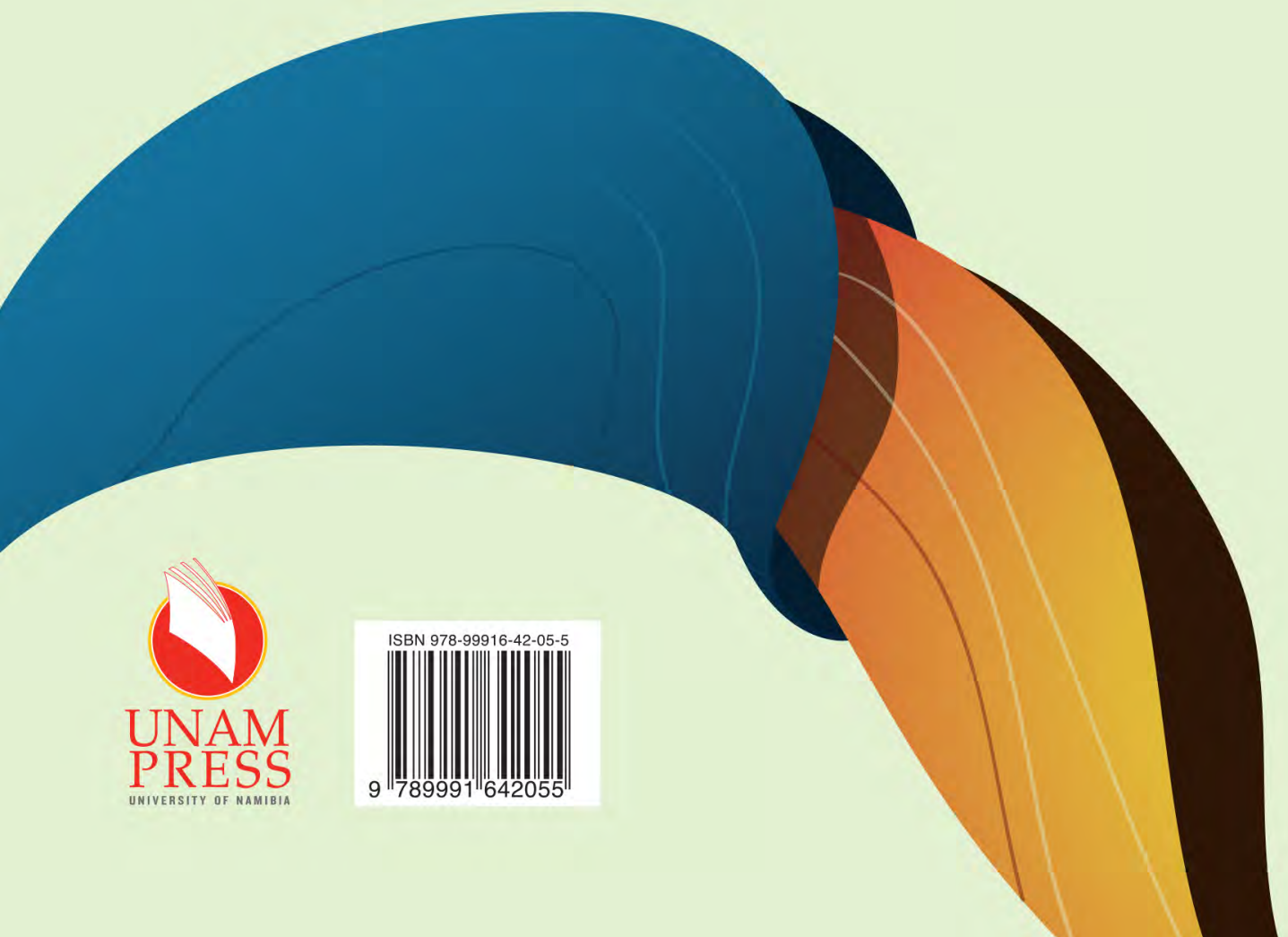




\title{
Indigenous Knowledge of Namibia
}

\author{
EDITED BY \\ Kazhila C. Chinsembu, Ahmad Cheikhyoussef, \\ Davis Mumbengegwi, Martha Kandawa-Schulz, \\ Choshi D. Kasanda and Lawrence Kazembe
}

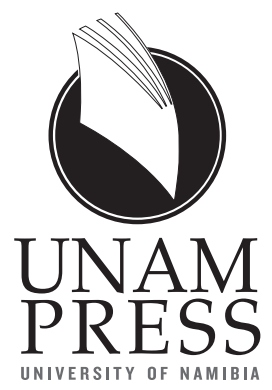


University of Namibia Press

www.unam.edu.na/unam-press

unampress@unam.na

Private Bag 13301

Windhoek

Namibia

(C) 'Introduction', Kazhila C. Chinsembu, 2015

(C) Individual chapters, stated authors, 2015

(C) Photographs, with photographers and sources cited

All rights reserved. No part of this publication may be reproduced, stored in any retrieval system or transmitted in any form, or by any means, e.g. electronic, mechanical, photocopying, recording or otherwise without prior permission of the author.

First published: 2015

Copy-editor: Carole Roberts

Design and layout: Vivien Barnes, Handmade Communications

Cover design: Nambowa Malua

Maps: Carole Roberts

Printed by: John Meinert Printers, Windhoek

ISBN 978-99916-42-05-5

The information presented in this book is for research and academic purposes only. Medicinal properties mentioned in this book do not necessarily point to the clinical efficacy and safety of the plants. Readers should not use any information in this book for self-medication, therapy and consumption of plant materials, foods and drinks. The publisher, editors and authors will not be liable for claims arising from the application or misapplication of data from this book.

Responsibility for the correct orthography of indigenous language terms lies with the authors.

UNAM Press has no responsibility for the persistence or accuracy of URLs for external or thirdparty internet websites referred to in this publication, and does not guarantee that any content on such websites is, or will remain, accurate or appropriate.

Distributed nationally by Namibia Book Market: www.namibiabooks.com;

email: contact@namibiabooks.com

In the rest of Southern Africa by Blue Weaver: www.blueweaver.co.za

Internationally by the African Books Collective: www.africanbookscollective.com 


\section{Contents}

Acknowledgments $\quad \mathrm{v}$

Abbreviations and acronyms vi

Introduction 1

1 Bioprospecting for 'green diamonds': Medicinal plants used in the 9 management of HIV/AIDS-related conditions

Kazbila C. Chinsembu

2 Indigenous use of plants to treat malaria and associated symptoms

Irwanette du Preez, Sylvia Nafuka, Davis R. Mumbengegwi छ Ronnie Böck

3 Indigenous knowledge of medicinal plants used for the treatment of cancer Florence Dushimemaria, Davis R. Mumbengegwi छ Ronnie Böck

4 The use of traditional medicinal plants as antimicrobial treatments Davis R. Mumbengegwi, Irwanette du Preez, Florence Dushimemaria, Joyce Auala E Sylvia Nafuka

5 Indigenous knowledge and antimicrobial properties of plants used in ethnoveterinary medicine

Kazbila C. Chinsembu

6 School learners' knowledge and views of traditional medicinal plant use in two regions in Namibia

Choshi Darius Kasanda \& Hileni Magano Kapenda

7 Namibian leafy vegetables: From traditional to scientific knowledge, current status and applications Lynatte F. Mushabati, Gladys K. Kahaka \& Abmad Cheikhyoussef

8 Traditionally fermented milk products

Lusia Heita \& Ahmad Cheikhyoussef

9 Oshikundu: An indigenous fermented beverage

Werner Embashu, Ahmad Cheikhyoussef E Gladys Kahaka 
10 Harvesting and consumption of the giant African bullfrog, a delicacy in northern Namibia

Daniel O. Okeyo, Lineekela Kandjengo E Martha M. Kashea

11 Indigenous knowledge used in the management of human-wildlife conflict along the borders of the Etosha National Park

Selma M. Lendelvo, Margaret N. Angula EJ John Kazgeba E. Mfune

12 Understanding indigenous coping strategies of the Basubiya on the flooded plains of the Zambezi River

Nchindo Richardson Mbukusa

13 Indigenous knowledge and climate change in rural Namibia:

A gendered approach

Nguza Siyambango, Alex T. Kanyimba E̊ Pempelani Mufunet

14 Reclaiming indigenous knowledge in Namibia's post-colonial curriculum:

The case of the Mafwe people

John Makala Lilemba E Yonah Hisbon Matemba

15 Developmental issues facing the San people of Namibia:

Road to de-marginalization in formal education

Anthony Brown E' Cynthy K. Haihambo

16 Messages given to adolescents and young adults during initiation ceremonies and their relation to HIV/AIDS

Cynthy K. Haihambo

17 To integrate or not: Exploring the prospects and challenges of integrating indigenous knowledge at the University of Namibia

Grace M. Mukumbo Chinsembu E' Miriam Hamunyela

Questions for students

Glossary

Contributors 


\section{Acknowledgments}

This book would not have been possible without the support received from Professor Frednard Gideon (Dean, Faculty of Science) and Dr Nelago Indongo (Director, Multidisciplinary Research Centre).

Photographs were supplied by the authors and Graham Alexander, Antje Burke, Dave Cole, Christopher Hines, Coleen Mannheimer, John Mendelsohn, Mark Paxton, Silke Rügheimer, George Sanzila and BCW van der Waal. UNAM Press acknowledges their support with gratitude. 


\section{Abbreviations and acronyms}

$\begin{array}{ll}\% & \text { degree(s) } \\ \text { ABS } & \text { per cent } \\ \text { access and benefit sharing } \\ \text { anno Domini (number of years after the birth of Christ) } \\ \text { alDS } & \text { African leafy vegetables } \\ \text { ALV } & \text { Association of Official Analytical Chemists } \\ \text { AOAC } & \text { antiretroviral therapy } \\ \text { ART } & \text { American Type Culture Collection } \\ \text { ATCC } & \text { number of years before the birth of Christ } \\ \text { bc } & \text { Bachelor of Indigenous Knowledge Systems } \\ \text { BIKS } & \text { Celsius } \\ \text { C } & \text { community-based natural resource management } \\ \text { CBNRM } & \text { United States Centers for Disease Control and Prevention } \\ \text { CDC } & \text { Caprivi Liberation Movement } \\ \text { CLM } & \text { centimetre(s) } \\ \text { Cm } & \text { carbon dioxide } \\ \text { CO } 2 & \text { Centre for Research Information Action in Africa Southern } \\ \text { CRIAA SA-DC } & \text { African Development and Consulting } \\ \text { CSIR } & \text { Council for Scientific and Industrial Research } \\ \text { DMSO } & \text { dimethyl sulfoxide } \\ \text { DNA } & \text { deoxyribonucleic acid } \\ \text { DPPH } & \text { 2,2-diphenyl-1-picrylhydrazyl } \\ \text { DRST } & \text { Directorate of Research, Science and Technology (ME) } \\ \text { DST } & \text { Department of Science and Technology (South Africa) } \\ \text { e.g. } & \text { for example } \\ \text { EMIS } & \text { Education Management Information System } \\ \text { ENP } & \text { Etosha National Park } \\ \text { et al. } & \text { et alii (and others) } \\ \text { EU } & \text { European Union }\end{array}$




$\begin{array}{ll}\text { EUR } & \text { Euro(s) } \\ \text { EVM } & \text { ethnoveterinary medicine } \\ \text { FAO } & \text { Food and Agriculture Organization of the United Nations } \\ \text { FMD } & \text { foot-and-mouth disease } \\ \text { g } & \text { gram(s) } \\ \text { GIBEX } & \text { Global Institute for Bioexploration } \\ \text { GIZ } & \text { Deutsche Gesellschaft für Technische Zusammenarbeit } \\ \text { GRN } & \text { Government of the Republic of Namibia } \\ \mathrm{H}_{2} \mathrm{O}_{2} & \text { hydrogen peroxide } \\ \text { ha } & \text { hectare(s) } \\ \text { HIV } & \text { human immunodeficiency virus } \\ \text { HWC } & \text { human-wildlife conflict } \\ \text { IBPC } & \text { Interim Bio-Prospecting Committee } \\ \text { IC } & \text { half maximal inhibitory concentration } \\ \text { IEK } & \text { indigenous ecological knowledge } \\ \text { IKS } & \text { indigenous knowledge systems } \\ \text { ILO } & \text { International Labour Organization } \\ \text { InWEnt } & \text { Capacity Building International, Germany } \\ \text { IBPC } & \text { Interim Bio-Prospecting Committee } \\ \text { IPTT } & \text { Indigenous Plant Task Team } \\ \text { LAB } & \text { lactic acid bacteria } \\ \mu \text { I } & \text { microlitre(s) } \\ \mu \text { Mg } & \text { microgram(s) } \\ \text { m } & \text { metre(s) } \\ \text { ME } & \text { Ministry of Education } \\ \text { MET } & \text { Ministry of Environment and Tourism } \\ \text { mg } & \text { milligram(s) } \\ \text { me } & \text { millilitre(s) } \\ \text { mm } & \text { millimetre(s) } \\ \text { MoHSS } & \text { Ministry of Health and Social Services (Namibia) } \\ \text { MRC } & \text { Multidisciplinary Research Centre (UNAM) } \\ \text { NAD } & \text { Namibia Dollar } \\ \text { NANASO } & \text { Namibia Network of AIDS Service Organizations } \\ \text { NBC } & \text { Namibia Broadcasting Corporation } \\ \text { NBF } & \text { Namibia Biosciences Forum } \\ \text { NBRI } & \text { National Botanical Research Institute } \\ \text { NCI } & \text { New Partnership for Africa's Development } \\ \text { NEPAD } & \end{array}$




$\begin{array}{ll}\text { NGO } & \text { non-government organization } \\ \text { NIKSO } & \text { National Indigenous Knowledge Systems Office } \\ \text { NLV } & \text { Namibian leafy vegetables } \\ \text { NPC } & \text { National Planning Commission } \\ \text { p. } & \text { page } \\ \text { PEPFAR } & \text { [USA] President's Emergency Plan for AIDS relief } \\ \text { pH } & \text { power of hydrogen ion concentration as a measure of acidity or } \\ & \text { alkalinity } \\ \text { pl. } & \text { plural } \\ \text { pp. } & \text { pages } \\ \text { RAEIN-Africa } & \text { Regional Agricultural and Environment Initiatives Network- } \\ & \text { Africa } \\ \text { RCT } & \text { rational choice theory } \\ \text { SANBio } & \text { Southern Africa Network for Biosciences } \\ \text { sing. } & \text { Singular } \\ \text { sp. } & \text { species (sing.) } \\ \text { spp. } & \text { species (pl.) } \\ \text { STAT3 } & \text { signal transducer and activator of transcription 3 } \\ \text { SWAPO } & \text { South West Africa People's Organization } \\ \text { TLC } & \text { thin-layer chromatography } \\ \text { UN } & \text { United Nations } \\ \text { UNAIDS } & \text { Joint United Nations Programme on HIV/AIDS } \\ \text { UNAM } & \text { University of Namibia } \\ \text { UNCED } & \text { United Nations Conference on Environment and } \\ & \text { Development } \\ \text { UNDP } & \text { United Nations Development Programme } \\ \text { UNESCO } & \text { United Nations Educational, Scientific and Cultural } \\ \text { UNFCCC } & \text { Organization } \\ \text { UNICEF } & \text { United Nations Framework Convention on Climate Change } \\ \text { USAID } & \text { United Nations Children's Fund } \\ \text { USA } & \text { United States Agency for International Development } \\ \text { USD } & \text { United States of America } \\ \text { VCF } & \text { United States Dollar } \\ \text { WHO } & \text { veterinary cordon fence } \\ \text { WIPO } & \text { World Health Organization } \\ \text { ZMW } & \text { World Intellectual Property Organization } \\ & \text { Zambian Kwacha } \\ & \end{array}$




\section{Introduction}

\section{Kazhila C. Chinsembu}

Why this book, Indigenous Knowledge of Namibia? Nowadays, indigenous knowledge has gained prominence and attracted public interest due to its numerous applications in science and innovation: biotechnology, health, bioprospecting, pharmaceuticals, medicinal plants, agriculture, food preparation, mathematics, natural resource management, climate change and astronomy.

There are many niche players in the field of indigenous knowledge in Namibia and many studies being carried out. Thus, although not all aspects of Namibia's indigenous knowledge are covered in this book, most readers from various walks of life - laypersons, scholars and policy makers - will find this book a very useful companion. The content of this book serves as a good starting point, because 'we cannot go further into the future without looking deeper into the past' (anonymous).

Through their laboratory and scientific studies, the authors of this book serve as guides through the journey to discover and record the indigenous knowledge of Namibian society. More importantly, their individual and collective works endeavour to add value to Namibia's indigenous knowledge. The voyage and value addition are aimed at bringing greater clarity to some of the most perplexing aspects of indigenous knowledge in Namibia.

Authors are aware that local communities need to benefit from their indigenous knowledge. That being said, the aim of this book is not to appropriate the indigenous knowledge of local communities, as most indigenous knowledge is already in the public domain. Rather, in line with Namibia's National Programme on Research, Science, Technology and Innovation (NPRSTI), the aim of this book is to 'ensure that indigenous knowledge is properly documented' (NCRST, 2014, p.14).

Many definitions and connotations of indigenous knowledge are provided in this book. However, it is important to note that indigenous knowledge is the foundation of Namibian society, an information base which facilitates communication and decision-making. It is dynamic, being continuously influenced by internal creativity, experimentation and external contacts. Moreover, indigenous knowledge is the 
cornerstone of many modern-day innovations in science and technology. It is also a ready and valuable resource for sustainable and resilient livelihoods.

A brief historical background and context to this book is imperative. The idea to write this book was conceived by Professor Kazhila C. Chinsembu in January 2012. A proposal was made to the Faculty of Science Academic Board meeting, University of Namibia (UNAM), which approved the book project. An invitation was later extended to research staff in UNAM's Multidisciplinary Research Centre (MRC) who agreed to collaborate with academics from the Faculty of Science. This book is therefore a joint collaborative effort of the Faculty of Science and MRC.

To operationalize the book project, book chapters were drawn from presentations made during the 2nd Symposium, Indigenous Knowledge Systems (IKS): From Concepts to Applications, organised from 8 to 9 October 2012, by IKST Food and Beverages Programme of the Science, Technology and Innovation Division of MRC. This was followed by a Book Writers' Workshop to assist potential authors to draft and develop their book chapters.

Briefly, the book is arranged in 17 chapters. The first six chapters are devoted to the indigenous knowledge of medicinal plants for treating HIV/AIDS-related symptoms and diseases, malaria, cancer, and other microbial infections of humans and livestock. These are followed by chapters $7-10$ which are assigned to indigenous foods, and chapters 11-13 that espouse the indigenous knowledge used to cope with human-wildlife conflicts and floods, as well as that which underpins the nexus of gender, climate change and management of natural resources.

Chapter 14 unravels the indigenous knowledge of the Mafwe ethnic group. Chapter 15 speaks to the challenges of harmonising modern education with that of the indigenous San people of Namibia. Chapter 16 urges a new rationalization of adolescent customary and initiation ceremonies in response to the HIV/AIDS pandemic. Chapter 17 sums it all up, offering a compelling argument for universities and other institutions of higher learning to rise to the occasion and integrate indigenous knowledge into existing or new degree programmes.

In Chapter 1, Chinsembu unpacks the indigenous knowledge of plants used to manage HIV/AIDS. Since Namibia is a diamondiferous country, Chinsembu introduces the term 'green diamonds' to refer to all the medicinal plants used in the management of HIV/AIDS in Namibia. Chinsembu agrees that while Namibia has made remarkable progress in the provision of antiretroviral therapy (ART) to HIV/AIDS patients, the country's ART programme is threatened by diminishing financial resources.

Given this shortcoming, there is reason to evaluate elements of traditional medicine, particularly medicinal plants and other natural products, that can yield effective and affordable therapeutic agents for conditions related to HIV/AIDS. Unfortunately, knowledge of ethnomedicines for HIV/AIDS is still vague and not well documented. Besides the problem of documentation, laws and administrative 
structures, public trust, and the lack of recognition of traditional healers continue to hamper the integration of traditional medicines within modern ART programmes. So, in Chapter 1, Chinsembu describes a contextual model for initiating collaboration with traditional healers as well as the repertoire of putative anti-HIV plants whose chemical constituents are being evaluated for possible development into novel antiretroviral drugs for AIDS.

Chapter 1 is part of a fresh corpus of scholarly works that draws on new empirical evidence about the medicinal efficacy of plants against HIV infection. This work overthrows the long-standing notion held by the medical and pharmaceutical fraternities that the crude aqueous extracts of medicinal plants, as used by traditional healers, are ineffective against HIV. Yet, most importantly, the antimicrobial and anti-HIV ethnobotanical data suggest an opportunity for inventing new drugs from Namibian flora.

Chapter 2, by Du Preez, Nafuka, Mumbengegwi and Bock, is on the indigenous knowledge of medicinal plants used to treat symptoms of malaria. Although malaria is on the decline in Namibia and the country is moving towards elimination of the disease by 2020 , the authors contend that local communities continue to use traditional medicines to manage the disease. Ethnomedicinal plants are used to treat malaria-like symptoms in regions where the disease is endemic.

The authors are careful to state that it is premature to conclude that herbal medicines can be used as effective antimalarials, for several reasons. Most of the literature on medicinal plant remedies in Namibia lacks detail and specificity, including locality, abundance and plant parts used; mode of preparation, dosage and period of treatment; and the active components present in plants. In this chapter, the authors present data from investigations on antiplasmodial properties of selected Namibian plants. The authors conclude that the presence of compounds with antiplasmodial action strongly supports the traditional use of the plants for managing malaria symptoms.

The authors of Chapter 3, Dushimemaria, Mumbengegwi and Bock, detail the different plants used by ethnic groups in Namibia as medicinal remedies for alleviation of cancer symptoms. The authors present results on the phytochemical screening of local plant materials for anticancer properties. The presence of antiprotease activities and phytochemicals such as coumarins, anthraquinones, alkaloids, triterpenoids and flavonoids justifies the use of these medicinal plants in the management of cancer in Namibia and beyond.

Chapter 4 analyses the indigenous knowledge of medicinal plants used for the treatment of microbial infections. Mumbengegwi, du Preez, Dushimemaria, Auala and Nafuka, using phytochemical screening of extracts, show the presence of classes of compounds associated with antimicrobial activity against oral pathogens, enterobacteria, food-borne and other opportunistic pathogens. 
Chapter 5 is about the exciting field of ethnoveterinary medicine (EVM). In this chapter, Chinsembu showcases the indigenous knowledge of plants used to treat livestock diseases. The rationale for EVM is simple. Small-scale and resource-poor livestock farmers cannot afford expensive synthetic pharmaceutical drugs. Therefore, they draw on their indigenous knowledge to unlock the power of EVM plants to treat animal diseases. However, there is no ethnoveterinary pharmacopeia and data on ethnoveterinary usage of plants are still sparse. In Chapter 5, ethnobotanical data from Namibia are briefly discussed within the prism of current knowledge of EVMs in selected African countries such as Botswana, Côte d'Ivoire, Ethiopia, Kenya, Nigeria, South Africa and Zambia.

Chapter 6 illustrates that indigenous knowledge is not just old-fashioned 'stuff' for the older folks. Kasanda and Kapenda, working with Junior High School learners in the Omusati and Oshana regions, show that high-school learners hold differing levels of knowledge on the use of traditional medicinal plants in curing common ailments and diseases. Female learners tend to be more knowledgeable of the traditional medicinal plants and their uses within their environment than male students. Interestingly, the majority of learners in this study are in favour of tuition on the use of traditional medicinal plants forming part of the science curriculum in Namibia. In retrospect, the authors also deduce that making the learners aware of the important use of medicinal plants will help preserve the plants for use by future generations.

In Chapter 7, Mushabati, Kahaka and Cheikhyoussef show that African leafy vegetables (ALVs) contain phytochemicals with medicinal value. Antimicrobial activities of the ALVs also confirm the urgent need to promote the consumption of ALVs as nutraceuticals, foods that provide medicinal or health benefits, including the prevention and treatment of diseases.

Heita and Cheikhyoussef in Chapter 8 delve into the indigenous knowledge of fermented milk products. The chapter focuses on three traditionally fermented milk products, namely omashikwa, mabisi and mashini ghakushika which are common in north-central and north-eastern Namibia. The authors isolate and identify key lactic acid bacteria (LAB), and analyse the physicochemical properties of the traditional milk products. Their results show the great potential in the microflora of these milk products, which can be used to control the fermentation process and thus extend the shelf life of most traditionally fermented milk products in Namibia.

Chapter 9 is about oshikundu, an indigenous, non-alcoholic fermented beverage. Here, the authors Embashu, Cheikhyoussef and Kahakareport on the physicochemical and nutrient content of this indigenous beverage. The importance of this research is to provide fresh insights into the possibility of extending the shelf life of oshikundu.

Whenever you need an indigenous food delicacy from Namibia, consider eating the African bullfrog. In Chapter 10, Okeyo, Kandjengo and Kashea appeal to our appetites. The authors dissect the indigenous knowledge surrounding the 
Aawambo consumption of the giant African bullfrog Pyxicephalus adspersus, which besides being a source of food, has medicinal uses as well. They also mention the indigenous practices for the treatment of oshiketaketa infections. Various folklore beliefs, observations by local people on the propagation of the frogs, and future multidisciplinary research recommendations are presented.

Indigenous knowledge shapes our coping and response strategies. Chapter 11 weaves together the indigenous knowledge used in the management of humanwildlife conflicts along the borders of an important national park in Namibia. Lendelvo, Angula and Mfune report findings of a study which investigated how both commercial and communal area farmers living around Etosha National Park use their indigenous knowledge in dealing with human-wildlife conflicts. The study revealed that farmers are aware of problem animals and identify them through their spoor, calls and behaviour. The authors conclude that the indigenous knowledge of farmers in the vicinity of Etosha National Park has shaped local human-wildlife conflict management responses.

Coping with floods can be a daunting task. Understanding the indigenous coping strategies of the Basubiya people on the flooded plains of the Zambezi River is an even more daunting task. But, in Chapter 12, Mbukusa helps readers to understand how the Basubiya people know the scale of the floods that surround them, what makes them enjoy the time of flooding, how they cope during the floods, and whether they will ever move from the floodplains to higher grounds. The author asserts the need for government policy makers and disaster management agencies to understand the indigenous knowledge and coping skills of the Basubiya in order to improve future flood management operations.

Chapter 13 provides a lens through which we can view and bring into sharp focus the gender-climate-change nexus. The authors, Siyambango, Kanyimba and Mufune (now deceased, may his soul rest in peace), examine the significance of indigenous knowledge, highlight some areas of climate-change vulnerability and resilience in which indigenous knowledge is relevant, and suggest a mechanism to make it explicit in rural Namibia. The chapter is largely conceptual or even contextual as it examines issues of climate change especially impacting girls and women in rural Namibia. The authors use several examples to interrogate a gendered approach in coping with climate-change-induced environmental and natural resources management issues such as drought, fetching water and firewood, subsistence livestock and crop agroecosystems, and the use of scarce medicinal plant resources to survive the threats of water- and vector-borne diseases.

In Chapter 14, Lilemba and Matemba, on reclaiming indigenous knowledge in Namibia's post-colonial curriculum, use the Mafwe people as a case study. The authors argue that during Namibia's colonization by Germany and South Africa, missionaries and colonial powers regarded the indigenous system of education as barbaric and an obstacle to the spread of Christianity and Western culture. Yet, before 
the advent of Eurocentric education, African communities used their indigenous knowledge-based education systems to survive many odds. Nowadays, scholars on indigenous knowledge are using systematic enquiry about indigenous philosophical ideas and issues that frame contemporary indigenous thought, perspective, and worldview. The authors suggest that African riddles, folklores and proverbs can be used to impart knowledge and skills to younger generations as this is compatible with modern western education. They urge that Namibian school curricula should also include indigenous knowledge to enhance learning and teaching.

Chapter 15 examines the case of the San people of Namibia. In this chapter, Mashego-Brown and Haihambo confront the developmental issues facing the San of Namibia. While the authors provide a hint of the 'pot-holed' road to de-marginalization and formal education, they also admit the San do and will generally remain poor because their children do not attend school to a satisfactory level - a warning sign that the San will remain inferior to other ethnic groups who use education as a pathway to poverty alleviation. The chapter reveals that amongst the San culture is inclusive in nature and those affected by HIV are accepted.

Mashego-Brown and Haihambo find the San of Namibia to be at a crossroads because amongst these indigenous people, some want to maintain their indigenous culture and indigenous education. They also want to maintain their indigenous health practices and direct dependency on the immediate environment for survival. But, ironically, another section wants to move with the times, to leave their indigenous culture behind, and to retain only part-time cultural practices compatible with modern education and practices.

In Chapter 16, Haihambo explores the messages communicated to adolescents and young adults during traditional initiation ceremonies and premarital counselling in Namibia. The main aim is to determine the degree to which such messages are adapted to national HIV/AIDS response strategies. Using research studies on the Aawambo, Ovaherero, Ovahimba and Damara ethnic groups, the author takes an ethnocentric walk and revisits the indigenous 'curricula' used by the various ethnic groups to advise adolescents on how to lead adult lives in a particular cultural context. As she found out, it would seem that because such curricula have been transmitted from generation to generation, the curricula are still so rigid that they exclude new developments such as HIV/AIDS, not to mention gender equality. The author recommends that traditional practices should evolve with the times and should therefore incorporate HIV content in their indigenous life skills and counselling programmes.

Finally, Chapter 17 urges the integration of indigenous knowledge into university studies. The authors, Grace Chinsembu and Miriam Hamunyela, investigate the perceptions of lecturers towards integrating indigenous knowledge into the university curriculum, showing that most lecturers support the concept. However, the challenges of integrating it into the curriculum include the following: unskilled person-power, 
lack of documentation, the non-scientific nature of indigenous knowledge, and different cultural backgrounds of students and lecturers. Despite these shortcomings, and given the strong paradigm shift to indigenous knowledge, the authors urge the University of Namibia either to integrate it into existing curricula or to implement new indigenous knowledge degree programmes and courses.

Indigenous Knowledge of Namibia is an important book that rekindles our interest in documenting indigenous knowledge because the libraries of this tacit knowledge are usually older people who are not part of educational establishments. As efforts are being made to mainstream indigenous knowledge into formal education, there is a need to document available indigenous knowledge in order to ensure its effective instruction, learning and preservation. This book is a modest effort to document Namibia's indigenous knowledge in a single corpus.

In conclusion, the editorial team thanks all the indigenous knowledge holders, the man and woman in the village, without whom this book would still be a figment of our imaginations. Be that as it may, the opinions and interpretations expressed in various chapters of the book are those of the respective authors, and not of the chief editor, assistant editors or the institutions they represent. Many thanks for reading Indigenous Knowledge of Namibia.

\section{Reference}

NCRST [National Commission for Research, Science and Technology]. (2014). The National Programme on Research, Science, Technology and Innovation (NPRSTI) 2014/15 to 2016/17. Windhoek: Author. 